\title{
Pengaruh Budaya Organisasi Terhadap Akuntabilitas Kepala Sekolah
}

\author{
Goinpeace Handerson Tumbel \\ UNIMA \\ Tondano, Indonesia \\ goinpeacetumbel@unima.ac.id \\ Anggun Switly Langkay \\ UNIMA \\ Tondano, Indonesia
}

Abstrak - Penelitian ini bertujuan untuk mengetahui pengaruh budaya organisasi terhadap akuntabilitas Kepala Sekolah SMA dan SMK se Kota Tomohon dengan menggunakan pendekatan kuantitatif dan teknik analisis regresi dan korelasi. Hasil penelitian menunjukkan bahwa : 1). Budaya organisasi secara signifikan tidak memberikan pengaruh besar terhadap akuntabilitas Kepala Sekolah di SMA dan SMK se Kota Tomohon., 2). Besar pengaruh budaya organisasi terhadap akuntabilitas ialah 13,4 \%. Berdasarkan kesimpulan tersebut maka disarankan bahwa : 1). Sebaiknya dilakukan penelitian dan kajian terhadap faktor-faktor dominan yang mempengaruhi akuntabilitas Kepala Sekolah di SMA dan SMK se Kota Tomohon., 2). Dilalukan evaluasi terhadap perubahan-perubahan tata kelola organisasi berdasar Peraturan Pemerintah (PP) Nomor 18 Tahun 2016 tentang Perangkat Daerah yang melaksanakan Urusan Pemerintahan bidang pendidikan.

Kata Kunci :Budaya Organisasi, Akuntabilitas Kepala Sekolah

\section{PENDAHULUAN}

Sejak 1 Januari 2017 pengelolaan pendidikan tingkat SMA dan SMK dipindahkan dari kewenangan pemerintah kabupaten/kota menjadi kewenangan pemerintah provinsi. Hal itu berdasarkan Undang-Undang Republik Indonesia Nomor 23 Tahun 2014 Tentang Pemerintahan Daerah pada Huruf A Lampiran yang menagatakan "pemerintah provinsi mengelola pendidikan menengah dan pendidikan khusus."
Kemudian pada Peraturan Pemerintah RI Nomor 18 Tahun 2016, penjelasan Pasal 22 bahwa "Perangkat Daerah yang melaksanakan Urusan Pemerintahan bidang pendidikan adalah Perangkat Daerah yang melaksanakan Urusan Pemerintahan bidang pendidikan, sub urusan manajemen pendidikan yang terkait dengan kewenangan pengelolaan pendidikan menengah dan pendidikan khusus."

Pada kenyataannya ada beberapa kota melakukan penolakan terkait dengan ketentuan tersebut sehingga melakukan gugatan kepada Mahkama Konstitusi dan hasil gugatan tersebut ternyata ditolak oleh pihak Makama Konstitusi. Makama Konstitusi berpendapat, yang menjadi persoalan selanjutnya yaitu apa yang dijadikan kriteria bahwa suatu urusan pemerintahan konkuren kewenangannya akan diberikan kepada Daerah (baik daerah provinsi atau daerah kabupaten/kota) atau akan tetap dipegang oleh Pemerintah Pusat. Undang-Undang tentang Pemerintahan Daerah menyatakan bahwa prinsip yang dijadikan dasar adalah prinsip akuntabilitas, efisiensi, dan eksternalitas, serta kepentingan strategis nasional.

Menurut Makama Konstitusi, pendidikan masuk dalam urusan pemerintah yang wajib dipenuhi karena berkaitan dengan pendidikan dasar. Berdasarkan keempat prinsip tersebut pembentuk undang-undang berpendapat bahwa pendidikan menengah lebih tepat diserahkan kepada daerah Provinsi, maka hal itu tidaklah bertentangan dengan UUD 1945. Hal itu 
merupakan kebijakan hukum pembentuk undangundang.

Melihat kecenderungan atau aspirasi yang berkembang di kalangan guru-guru SMA/SMK, mereka mengharapkan SMA/SMK dikelola oleh pemerintah provinsi daripada oleh pemerintah kabupaten atau kota dengan alasan: pertama, guru SMA/SMK menjadi objek politisasi, khususnya menjelang pemilihan kepala daerah. Para guru SMA/SMK tersebut ingin bebas dari bayangbayang politisasi pada saat pemilihan kepala daerah. Kedua, pelayanan yang dinilai kurang optimal dan kurang profesional dari jajaran birokrasi Dinas Pendidikan terhadap guru-guru SMA/SMK, misalnya keterlambatan informasi, adanya perlakuan pilih kasih terhadap guru, kurang terbukanya dan meratanya informasi atau kesempatan peningkatan profesionalisme dan karir guru SMA/SMK, sehingga menimbulkan kecemburuan sosial di antara mereka. Dengan kata lain, political will pemerintah kabupaten/kota dalam mengelola pendidikan di SMA/SMK dinilai masih rendah. Ketiga, harapan peningkatan kesejahteraan. Harapan tersebut sah-sah saja karena walaupun mereka telah mendapatkan tunjangan profesi, juga mengharapkan ada tunjangan lain untuk meningkatkan kesejahteraannya.

Dengan diberlakukannya kebijakan pemerintah yang dimaksud, berimplikasi pada organisasi tata kerja yang ada di setiap sekolah SMA dan SMK termasuk budaya organisasinya. Sebelum peraturan ini berlaku, maka kultur kerjanya berpijak pada ketentuan Kementerian Dalam Negeri yang merupakan kementerian pembina kabupaten/kota, dengan kata lain tata kelola dan aturan didasari pada visi dan misi pemerintah kabupaten dengan budayanya yang didasari pada prinsip desentralisasi (otonomi daerah). Namun setelah peralihan kewenangan pengelolan ke provinsi maka, tata kelola dan aturan didasari pada visi dan misi pemerintah provinsi dengan budayanya yang didasari pada prinsip dekonsentrasi (Pelimpahan Tugas pemerintah pusat kepada pejabatnya yang berada di daerah).
Penelitian terhadap prinsip yang dijadikan kewenangan pengelolaan SMA dan SMK oleh pemerintah provinsi berdasarkan UU RI Nomor 23 tahun 2014 soal prinsip akuntabilitas, efisiensi, dan eksternalitas, serta kepentingan strategis nasional sudah terlaksna dengan baik bila dikaitkan dengan budya organisasi yang telah berubah dalam hal peran seorang kepal sekolah dalam mewujudkan prinsip-prinsip tersebut di atas, terutama prinsip akuntabilitas.

Kepala sekolah adalah guru yang diberi tugas tambahan untuk memimpin satuan pendidikan formal. Peraturan Menteri Pendidikan Nasional Republik Indonesia Nomor 13 Tahun 2007 tentang Standar Kepala Sekolah/Madrasah menetapkan standar kompetensi yang harus dimiliki oleh kepala sekolah dalam menjalankan tugas dan fungsinya yaitu kompetensi kepribadian, manajerial, supervisi, kewirausahaan, dan sososial, sehingga adanya perubahan kewenangan pengelolaan sekolah tingkat SMA dan SMK, kepentingannnya sangat ditentukan oleh peran seorang kepala sekolah. Berdasarkan persoalan di atas, maka peneliti merumuskan judul penelitiannya sebagai berikut: Pengaruh Budaya Organisasi Terhadap Akuntabilitas Kepala Sekolah SMA dan SMK se Kota Tomohon.

\section{KAJIAN PUSTAKA}

\section{Akuntabilitas}

Akuntabilitas berasal dari istilah dalam bahasa Inggris yaitu accountability, yang berarti pertanggunganjawaban atau keadaan untuk dipertanggungjawabkan atau keadaan untuk diminta pertanggungjawaban (Salim, 1991). Menurut Suherman (2009) "akuntabilitas yaitu berfungsinya seluruh komponen penggerak jalannya kegiatan perusahaan, sesuai tugas dan kewenangannya masing-masing."

Mardiasmo (2004), membahas tentang akuntabilitas dimana "akuntabilitas adalah merupakan kewajiban pemegang tugas dalam bentuk pertanggung jawaban, dengan cara menyajikan, melaporkan, mengungkapkan setiap 
aktifitas kepada pihak pemberi tugas.” Kedua definisi tersebut sependapat mengatakan bahwa akuntabilitas merupakan pertanggungjawaban atas segala yang dilakukan oleh pimpinan atau lembaga yang memberi wewenang dan akuntabilitas merupakan prinsip yang menjamin bahwa setiap kegiatan suatu organisasi atau perorangan dapat dipertangungjawabkan secara terbuka kepada masyarakat.

\section{Indikator Akuntabilitas}

Dari penjelasan yang bersumber dari Hopwood dan Tomkins, dalam Widodo, Joko, (2008) indikator akuntabilitas adalah sebagai berikut:

a. Akuntabilitas Hukum dan Kejujuran

1. Kepatuhan terhadap hukum.

2. Penghindaran korupsi dan kolusi

a. Akuntabilitas Proses yaitu adanya:

1. Kepatuhan terhadap prosedur

2. Pelayanan publik yang responsif

3. Pelayanan publik yang cermat

4. Pelayanan publik yang biaya murah

b. Akuntabilitas program yaitu :

1. Memberikan hasil yang optimal

2. Mempertanggung jawabkan yang telah dibuat

c. Akuntabilitas Kebijakan

Yaitu bertanggung jawab atas kebijakan yang telah diambil.

\section{Budaya Organisasi}

Menurut G Graham dalam Siswadi (2012:71) "budaya organisasi adalah norma, keyakinan, sikap dan filosofi organisasi. Kebudayaan adalah suatu sistem nilai, keyakinan dan norma-norma yang unik yang dimiliki bersama oleh setiap anggota organisasi yang menjadi penyebab penting bagi keefektifan suatu organisasi." Selain pengertian tersubut, Robbins dalam Sembiring, (2012:41) memberikan pengertian "budaya organisasi bahwa budaya organisasi mengacu ke sistem makna bersama dianut oleh anggota- anggota yang membedakan dengan organisasi lain."

Dapat disimpulkan bahwa budaya organisasi adalah pola keyakinan dan nilai-nilai organisasi yang dijiwai oleh anggotanya dalam melakukan pekerjaan sebagai cara yang tepat untuk memahai, memikirkan juga merasakan masalah terkait, sehingga akan menjadi suatu nilai atau aturan pada organisasi tersebut.

\section{Dimensi Budaya Organisasi}

Menurut Robbins dalam Tika (2006) terdapat beberapa karakteristik yang apabila dicampur dan dicocokkan maka akan menjadi budaya internal yaitu :

a. Inisiatif individu yaitu sejauh mana organisasi memberikan kebebasan kepada setiap pegawai dalam mengemukakan pendapat atau ide-ide yang di dalam pelaksanaan tugas dan fungsinya.

b. Pengarahan yaitu sejauh mana pimpinan suatu organisasi dapat menciptakan dengan jelas sasaran dan harapan yang diinginkan, sehingga para pegawai dapat memahaminya dan segala kegiatan yang dilakukan para pegawai mengarah pada pencapaian tujuan organisasi.

b. Integrasi yaitu sejauh mana suatu organisasi dapat mendorong unit-unit organisasi untuk bekerja dengan cara yang terkoordinasi.

c. Kontrol yaitu adanya pengawasan dari para pimpinan terhadap para pegawai dengan menggunakan peraturan-peraturan yang telah ditetapkan demi kelancaran organisasi.

d. Sistem imbalan, menurut Siagian dalam Handoko (2003:102) "adalah pemberian salah satu bentuk penghargaan kepada karyawan atas sumbanganya kepada organisasi terutama tercermin dari prestasi karyanya, imbalan yaitu sejauh mana alokasi imbalan (seperti kenaikan gaji, promosi, dan sebagainya) didasarkan atas prestasi kerja pegawai."

e. Pola komunikasi yaitu sejauh mana komunikasi dalam organisasi yang dibatasi oleh hierarki kewenangan yang formal dapat berjalan baik. 


\section{METODE PENELITIAN}

\section{Lokasi Penelitian}

Penelitian dilaksanakan di Kota Tomohon.

\section{Populasi dan Sampel}

1. Populasi

Dikarenakan jumlah guru (PNS) yang menjadi populasi dalam peneltian ini berjumlah 283, maka populasi dalam penelitian ini diambil $25 \%$ dari populasi yaitu sebesar 70 orang.

\section{Teknik Pengumpulan Data}

Adapun teknik pengumpulan data yang digunakan dalam penelitian ini adalah:

\section{Teknik angket}

Teknik angket sebagai teknik utama. Angket ini mengukur variabel dalam penelitian ini, dimana menyediakan beberapa pertanyaan yang akan diberikan kepada subjek penelitian untuk memberikan respon terhadap pertanyaan tersebut.

2. Wawancara

Teknik ini digunakan untuk mendapatkan informasi atau keterangan langsung dari responden/informasi sekaligus sampel mengenai permasalahan yang diteliti.

\section{Definisi Operasional Variabel}

Definisi operasional variabel merupakan batasan-batasan yang dipakai penulis untuk menghindari adanya interprestasi yang berbeda terhadap variable yang diteliti, sehingga setiap variabel perlu dioperasional. Adapun definisi tersebut adalah sebagai berikut:

\section{a. Akuntabilitas Kepala Sekolah}

Akuntabilitas adalah kewajiban pihak pemegang amanah (agent) untuk memberikan pertanggung jawaban, menyajikan, melaporkan, dan mengungkapkan segala aktifitas dan kegiatan yang menjadi tanggung jawabnya kepada pihak pemberi amanah (prinscipal) yang memiliki hak dan kewenangan untuk meminta pertanggung jawaban tersebut. Adapun indikatornya adalah
1). Akuntabilitas Hukum dan Kejujuran
2). Akuntabilitas Proses
3). Akuntabilitas program

4). Akuntabilitas Kebijakan

(Hopwood dan Tomkins dalam Widodo, Joko, 2008)

b. Budaya Organisasi

Budaya organisasi bahwa budaya organisasi mengacu ke sistem makna bersama yang dianut oleh anggota-anggota yang membedakan organisasi itu dari organisasiorganisasi lain. Adapun indikator sebagai berikut :

1). Inisiatif individu

2). Pengarahan

3). Integrasi

4). Kontrol

5). Sistem imbalan

6). Pola komunikasi

(Robbins dalam Tika, 2006:10)

\section{Skala Pengukuran}

Skala yang digunakan adalah skala Likert 1 sampai dengan 5. Untuk keperluan data kuantitatif, maka penilaian jawaban dapat dinilai sebagai berikut :

a. Sangat Setuju $(\mathrm{SS})=5$

b. Setuju $(S)=4$

c. Cukup setuju (CS) $=3$

d. Tidak Setuju (TS) $=2$

e. Sangat Tidak Setuju $($ STS $)=1$

Untuk mengukur variabel ini maka digunakan instrumen berupa kuisoner atau angket yang diajukan kepada responden dengan menggunakan skala ordinal pada item-item pertanyaan, dan setiap pertanyaan memuat alternatif jawaban yang mengandung perbedaan antara jawaban yang satu dengan yang lain. Terkait dengan pemberian bobot tersebut, maka dapat diuraikan bahwa option (pilihan Jawaban) a diberikan bobot dengan nilai 5, untuk option (pilihan jawaban) b diberikan bobot dengan nilai 4, untuk option (pilihan jawaban) c diberikan bobot dengan nilai 3, untuk option (pilihan jawaban) d diberikan bobot dengan nilai 2 dan untuk option (pilihan jawaban) e diberikan bobot dengan nilai 1.

\section{Pengujian Instrumen Variabel}

1. Uji Validitas 
Validitas adalah ketepatan atau kecermatan suatu instrument dalam mengukur apa yang ingin di ukur (Priyatno, 2008:16). Uji validitas sebuah data bertujuan untuk mengetahui sejauh mana validitas data yang diperoleh dari penyebaran kuesioner. Uji validitas adalah esenIs kebenaran penelitian. Sebuah instrument dikatakan valid apabila mampu mengukur apa yang hendak diukur serta dapat mengungkapkan data dan variabel yang akan diteliti secara tepat.

2. Uji Reliabilitas

Pengujian reliabilitas dalam penelitian ini dilakukan dengan menghitung Cronbach Alpha dari masing-masing item pertanyaan dalam suatu variabel (Nasution, 2003:23). Adapun rumusnya sebagai berikut:

$$
\alpha=\frac{k r}{1+(k-1) r}
$$

Dimana :

$\alpha=$ koefisien reliabilitas

$\mathrm{r}=$ koefisien rata-rata korelasi antar variabel

$\mathrm{k}=$ jumlah variabel dalam persamaan

Suatu instrumen dikatakan handal jika nilai Cronbach Alpha> 0,60 (Ghozali,2002:52).

\section{Metode Analisis Data}

\section{Uji Normalitas}

Uji Normalitas data bertujuan untuk mengetahui apakah dalam regresi, variabel dependen, variabel independen atau kedua-duanya mempunyai distribusi data normal atau mendekati normal (Santoso, 2004:212). Uji Normalitas data dilakukan dengan menggunakan kolmogrovsmirnov test dengan menetapkan derajat keyakinan $(\alpha)$ sebesar 5\%. Uji ini dilakukan pada setiap variabel dengan ketentuan bahwa jika secara individu masing-masing variabel memenuhi asumsi normalitas, maka secara simultan variabel-variabel tersebut juga bias dinyatakan memenuhi asumsi normalitas. Criteria pengujian ini melihat barisan kolmogrovsmirnov test adalah sebagai berikut :

a. Jika signifikan >0,05 maka data tersebut berdistribusi normal b. Jika signifikan $<0,05$ maka data tersebut tidak berdistribusi normal

\section{Uji Homogenitas}

Setelah melakukan uji normalitas, untuk mengetahui bahwa sampel memiliki varians yang homogen atau tidak, maka dilakukan uji homogenitas varians dengan rumus :

$$
F=\frac{\text { Varians Terbesar }}{\text { Varians Terkecil }}(\text { Sudjana, 2005: 250) }
$$

Nilai $F_{\text {hitung }}$ dibandingkan dengan nilai $F_{\text {tabel }}$. Apabila nilai $F_{\text {hitung }}<F_{\text {tabel }}$, maka populasi memiliki varians yang homogen. Untuk mencari $F_{\text {tabel }}$ pada uji homogenitas ini menggunakan tabel distribusi $\mathrm{F}$ dengan $\mathrm{dk}=\mathrm{n}-1$ dan taraf signifikansi $(0,05)$.

\section{Uji Linieritas}

Uji linearitas bertujuan untuk mengetahui apakah dua variabel mempunyai hubungan yang linear atau tidak secara signifikan. Uji ini digunakan sebagai prasyarat statistik parametrik khususnya dalam analisis korelasi atau regresi linear yang termasuk dalam hipotesis assosiatif. jadi bagi kita yang mengerjakan Skripsi berjudul "Korelasi antara....", "Hubungan antara......", atau "Pengaruh antara.....", uji linieritas ini harus kita lalui terlebih dahulu sebagai prasyarat uji hipotesis yang kita munculkan.

Pengujian dapat dilakukan pada program SPSS dengan menggunakan Test for Linearity pada taraf signifikansi 0,05 . Dua variabel dikatakan mempunyai hubungan yang linear bila signifikansi (Deviation from Linearity) lebih dari 0,05. (Priyatno Duwi 2012: 14).

\section{Pengujian Hipotesa}

1. Analisis Regresi Linier Sederhana

Untuk mengetahui Pengaruh Budaya Organisasi Terhadap Akuntabilitas Tugas Kepala Sekolah digunakan fungsi regresi linier sederhana. Dengan rumus (Supranto, 2008:180)

$\mathrm{Y}=\mathrm{a}+\mathrm{bX}$

Dimana :

$\mathrm{Y}=$ Budaya Organisasi

$\mathrm{X} 1=$ Akuntabilitas Tugas

$\mathrm{a}=$ konstanta 
$\mathrm{b}=$ koefisien regresi $\mathrm{X}$ terhadap variabel $\mathrm{Y}$

Dengan menggunakan analisis regresi linier ini maka peneliti akan mengetahui ada tidaknya Pengaruh Budaya Organisasi Terhadap Akuntabilitas Tugas Kepala Sekolah. Analisis ini diolah dengan bantuan program SPSS (Statistic Program for Social Science) 22.0 for Windows.

\section{Uji Korelasi Sederhana}

Analisis korelasi sederhana (Bivariate Correlation) digunakan untuk mengetahui keeratan hubungan antara dua variabel dan untuk mengetahui arah hubungan yang terjadi. Koefisien korelasi sederhana menunjukkan seberapa besar hubungan yang terjadi antara dua variabel.

Adapun rumusnya adalah:

$$
{ }_{x y}^{r}=\frac{n \cdot \Sigma_{x y}-\left(\Sigma_{x}\right)\left(\Sigma_{y}\right)}{\sqrt{\left.\left(n \cdot \Sigma_{x_{2}}-\left(\Sigma_{x}\right)^{2}\right) \cdot\left(n \cdot \Sigma_{y z}\right)-\left(\Sigma_{y}\right)^{2}\right)}}
$$

Sedangkan arti harga $r$ akan dikonsultasikan dengan Tabel interpretasi Nilai r sebagi berikut.

Interpretasi Koefisien Koorelasi Nilai r

$\begin{array}{ll}\begin{array}{l}\text { Interval } \\ \text { Koefisien }\end{array} & \begin{array}{l}\text { Tingkat } \\ \text { Hubungan }\end{array} \\ 0,80-1,000 & \text { Sangat tinggi } \\ 0,60-0,799 & \text { Tinggi } \\ 0,40-0,599 & \text { Cukup } \\ 0,30-0,399 & \text { Rendah }\end{array}$

\section{Mengukur Koofisen Determniasai}

Selanjutnya untuk menyatakan besar kecilnya sumbangan variabel $\mathrm{X}$ terhadap $\mathrm{Y}$ dapat ditentukan dengan rumus koefisien diterminan sebagai berikut.

$$
\begin{aligned}
& \mathrm{KP}=\mathrm{r}^{2} \times 100 \% \\
& \begin{array}{c}
\text { keterangan: } \mathrm{KP} \\
\text { Koefisien Diterminan }
\end{array}
\end{aligned}
$$

Koefisien Korelasi

engujian lanjutan yaitu uji signifikansi yang berfungsi apabila peneliti ingin mencari makna hubungan variabel $\mathrm{X}$ terhadap $\mathrm{Y}$, maka hasil korelasi PPM tersebut diuji dengan uji Signifikansi dengan rumus :

$$
\mathrm{t}_{\text {hitung }}=\frac{\mathrm{r} \sqrt{\mathrm{n}-2}}{\sqrt{1-r^{2}}}
$$

keterangan: $\quad t_{\text {hitung }}=$ Nilai $\mathrm{t}$

$\mathrm{r} \quad=$ Nilai Koefisien korelasi

$$
\mathrm{n} \quad=\text { Jumlah Sampel }
$$

\section{PEMBAHASAN DAN PENELITIAN}

Berdasarkan hasil penelitian yang diperoleh melalui analisis data yang telah dilakukan, dalam bagian ini disajikan pembahasan terhadap hasil-hasil penelitian tersebut, yaitu sebagai berikut :

1. Budaya organisasi

Secara umum peran budaya organisasi dalam pelaksanaan tugas kependidikan di SMA dan SMK se Kota Tomohon cukup baik dengan $74,49 \%$ atau total skor sebesar 2607 dari total maksimal skor 3500 sesuai skala pengukuran rating scale $I$. Hasil ini menujukan bahwa budaya organisasi yang ada di sekolah-sekolah yang menjadi lokasi penelitian sudah terbentuk secara baik.

Inisiatif individu yaitu sejauh mana organisasi memberikan kebebasan kepada setiap pegawai dalam mengemukakan pendapat atau ideide yang di dalam pelaksanaan tugas dan fungsinya. Inisiatif individu tersebut perlu dihargai oleh kelompok atau pimpinan suatu organisasi sepanjang menyangkut ide untuk memajukan dan mengembangkan organisasi.

Inisiatif guru-guru pengajar di masing-masing sekolah tersebut dapat dipastikan sudah berjalan dengan baik dalam rangka mengajar di kelas. Dengan demikian telah terjadi suatu proses penghargaan terhadap guru-guru yang melakukan upaya-inisitif dalam rangka mengembangankan cara mengajar sebagai tugas mereka. 
Adapun indikator paling rendah dalam eksitensi budaya organisasi di sekolah SMK dan SMA se Kota Tomohon adalah indikator integrasi di mana Kepala sekolah memberikan pengarahan dengan jelas sehingga bisa dilaksanakan dengan persentase pencapaian sebesar $71,71 \%$. Integrasi yaitu sejauh mana suatu organisasi dapat mendorong unit-unit organisasi untuk bekerja dengan cara yang terkoordinasi. Menurut Handoko (2003 : 195) "koordinasi merupakan proses pengintegrasian setiap tujuan dan kegiatan pada unit-unit yang terpisah (departemen atau bidang-bidang fungsional) suatu organisasi untuk mencapai tujuan."

Dari data tersebut di atas menegaskan walaupun nilainya menunjukan paling rendah diantara 9 (sembilan) indikator lainnya namun tidak tegolong buruk karena berada di atas 70 persen nilainya. Namun demikian, apa ynag menjadi tugas kepala sekolah sebagai pemimpin harus ditingkatkan sehingga mencapai hasil yang maksimal.

\section{Akuntabilitas Kepala Sekolah.}

Akuntabilitas kepala sekolah yang ada di setiap sekolah SMA dan SMK se Kota Tomohon menunjukan bahwa pelaksnaannya sudah masuk kategori cukup dalam pelaksanaanya, dimana sebesar persentase pelaksnaannya mencaiapai 73,33\%. Namun demikian hal tersebut menunjukan pula bahwa akuntabilitas kepala sekolah harus ditingkatkan agar mendapatkan hasil yang maksimal.

Berdasarkan analisi data pada variabel akuntabilitas kepala sekolah menunjukan bahwa indikator Akuntabilitas Hukum dan Kejujuran pada pernyataan Kepala sekolah patuh terhadap hukum nilai yang paling tinggi di antara 7 pertanyaan penelitian yang mencapai $80,5 \%$. Akuntabilitas hukum dan kejujuran adalah akuntabilitas lembaga-lembaga publik untuk berprilaku jujur dalam bekerja dan mentaati ketentuan hukum yang berlaku. Penggunaan dana publik harus dilakukan secara benar dan telah mendapatkan otorisasi.
Dari data di atas dapat dinyatakan bahwa akuntabilitas kepala sekolah SMA dan SMK se Kota Tomohon dalam pelaksnaannya patuh terhadap hukum dan peraturan lain yang disyaraktan dalam menjalankan organisasi dan jujur adanya praktik organisasi yang sehat tidak terjadi malpraktek dan maladministras. Widodo, Joko, (2008).

Di sisi lain, berdasarkan indikator akuntabilitas kepala sekolah yang dijabarkan kedalam 7 pertanyaan terdapat indikator yang memiliki nilai paling rendah pada variabel akuntabilitas publik yaitu akuntabiltas kebijakan dengan pertanyaan Kepala sekolah selalu mempertanggungjawabkan apa yang dikerjakan. Adapun persentase pencapaiannya adalah $70 \%$ atau skor nilai 245 dari 350 skor maksimal. Akuntabilitas kebijakan terkait dengan pertanggung jawaban lembaga publik atas kebijakan-kebijakan yang diambil.

Ini berarti bahwa kepala sekolah harus mempertanggungjawabkan semua pelaksnaan tugasnya kepada setiap elemen sekolah dalam bentuk yang dapat diketahui secara jelas oleh elemen yang dimaksud, misalnya laporan tertulis. Hal-hal yang harus diperhatikan dalam pertanggungjawaban tersebut adalah menyangkut pertimbangan munculnya kebijakan, tujuan kebijakan, sasaran, serta dampaknya. Dalam hal ini, pencapaian dalam hal ini harus ditingkatkan.

\section{PENUTUP}

\section{KESIMPULAN}

Dari pembahasan dan uraian yang telah dikemukakan pada bab sebelumnya, maka dapat diambil kesimpulan sebagai berikut.

1. Budaya organisasi secara signifikan tidak memberikan pengaruh besar terhadap akuntabilitas kepala sekolah yang terjadi saat ini pada SMA dan SMK se Kota Tomohon.

2. Besar pengaruh budaya organisasi terhadap akuntabilitas ialah $13,4 \%$. 


\section{SARAN}

Sesuai dengan hasil penelitian, pembahasan dan kesimpulan sebagai akhir dari penulisan skripsi ini, peneliti merumuskan beberapa saran :

1. Sebaiknya dilakukan penelitian dan kajian terhadap faktor-faktor yanmg dominan mempengaruhi akuntabilitas kepala sekolah di SMA dan SMK se Kota Tomohon.

2. Dilakukan evaluasi terhadap perubahanperubahan tata kelola organisasi sesuai Peraturan Pemerintah (PP) Nomor 18 Tahun 2016, yaitu yang dimaksud dengan "Perangkat Daerah yang melaksanakan Urusan Pemerintahan bidang pendidikan adalah Perangkat Daerah yang melaksanakan Urusan Pemerintahan bidang pendidikan, sub urusan manajemen pendidikan yang terkait dengan kewenangan pengelolaan pendidikan menengah dan pendidikan khusus."

\section{REFERENSI}

[1] Arikunto, Suharsimi. 1998. Prosedur Penelitian Suatu Pendekatan dan Praktek. Jakarta: Rineka Cipta

[2] Ghozali, Imam. 2002. Aplikasi Analisis Multivariate dengan ProgramSPSS (4th ed.).Semarang:BadanPenerbit- Undip.

[3] Handoko,T. Hani. 2003.Manajemen. Yogyakarta: Fakultas Ekonomi Universitas Gadjah Mada

[4] Mardiasmo. (2004). Membangun Akuntabilitas Publik Keuangan Negara.Media Akuntansi 39/April/Tahun XI/2004, Hal 12.

[5] Nasution, 2003. Metode Research, Jakarta : PT. Bumi Aksara.

[6] Priyatno Duwi, 2012. Belajar Cepat Olah Data Statistik dengan SPSS, C.V. ANDI OFFSET, Yogyakarta.
[7] Salim, P. 1991. Kamus Bahasa Kontemporer. Jakarta : Modern English Fresh.

[8] Santoso. (2004). Mengatasi Berbagai Masalah Statistik dengan SPSS versi 11.5. Jakarta: Gramedia.

[9] Sembiring, Masana. 2012. Budaya dan Kinerja Organisasi. Fokusmedia. Bandung. Pertiwi, A.K. (2009).

[10] Siswadi, Edi. 2012. Birokrasi Masa Depan . Mutiara Press. Bandung.

[11] Sudjana. 2005. Metode Statistika Edisi ke-6. Bandung : Tarsito.

[12] Sugiyono. 2013. Metode Penelitian Pendidikan (Pendekatan Kuantitatif, Kualitatif, dan R\&D).Bandung : Alfabeta.

[13] Suherman. 2009. Perpustakaan sebagai Jantung Sekolah. Bandung: MQS Publishing.

[14] Supartono, 2004. Ilmu Budaya Dasar , Bogor, Ghalia Indonesia

[15] Supranto. 2008. Statistika Teori dan Aplikasi. Edisi Ketujuh. Jakarta: Erlangga.

[16] Tika, P.(2006).Budaya Organisasi dan Peningkatan Kinerja Perusahaan.Jakarta: PT. Bumi Aksara.

[17] Widodo, Joko, (2008), Good Governance; Telaah dan dimensi Akuntabilitas Birokrasi pada Era Desentralisasi dan Otonomi Daerah, Surabaya: Instan Cendikia.

[18] Huruf A Lampiran UU RI Nomor 23 Tahun 2014 Tentang Pemerintahan Daerah.

[19] Peraturan Pemerintah (PP) Nomor 18 Tahun 2016 Tentang Perangkat Daerah. 